\title{
Commentary on Canadian Foundation for Children, Youth and the Law v Canada (Attorney General)
}

\author{
Lucinda Ferguson
}

\section{Introduction}

Physical punishment ${ }^{1}$ of children can occur at the hands of the state-in school, care or other institutional settings - or private individuals-parents, other family members and individuals involved in raising the child. Legal systems must choose whether to directly regulate physical punishment. If not specifically regulated, the general law-child protection, criminal, contract and tort law-applies. Specific regulation can increase the legal justification or excuse beyond that which would otherwise trigger state intervention. An absolute ban has the appearance of specific regulation but simply means that the general law applies. ${ }^{2}$

As at 30 November 2016, 51 states prohibit all forms of physical punishment of children in all settings. ${ }^{3}$ Canada and the UK have ratified but not incorporated the Convention on the Rights of the Child (CRC). ${ }^{4}$ Despite legal challenges, both jurisdictions continue to prefer specific regulation in the form of particular defences, 'reasonable

\footnotetext{
${ }^{1}$ I adopt this terminology to cover the full range of acts: 'corporal punishment' is sometimes understood to refer to only severe acts, hence the language itself incorporates a de minimis exclusion. See Joan E Durrant, Ron Ensom, and Coalition on Physical Punishment of Children and Youth, Joint Statement on Physical Punishment of Children and Youth (Coalition on Physical Punishment of Children and Youth, 2004) 2.

${ }^{2}$ As I discuss below in relation to the language of 'children's rights' and 'rights for children', however, the expressive aspect of an absolute ban may be critical.

${ }^{3}$ Global Initiative to End Corporal Punishment of Children, 'States which have prohibited all corporal punishment', online: www.endcorporalpunishment.org/progress/prohibiting-states/.

${ }^{4}$ United Nations' Convention on the Rights of the Child (20 November 1989), 1577 UNTS 3.

${ }^{5}$ This is to be distinguished from general law defences, such as the posited de minimis defence to common law liability in criminal law, discussed below.
} 
correction' $^{6}$ and 'reasonable punishment" ${ }^{7}$ respectively, which heighten the legal protection against criminal law liability for the use of physical punishment. Section 43 of the Canadian Criminal Code ${ }^{8}$ explicitly 'justifie $[s]^{\prime 9}$ the reasonable use of force by way of correction in the context of assault under section 265 of the Criminal Code. As written, the Canadian defence applies to schoolteachers, ${ }^{10}$ parents and persons standing in the place of parents, whereas the UK defence has been legislatively excluded from application to schools ${ }^{11}$ and childminders. ${ }^{12}$

II. The Original Decision in Canadian Foundation for Children, Youth and the Law v Canada (Attorney General) ${ }^{13}$

The Supreme Court of Canada's decision in Canadian Foundation remains the leading authority on the interpretation of section 43 . The case involved a constitutional challenge, ${ }^{14}$

\footnotetext{
${ }^{6}$ Criminal Code, RSC 1985, c C-46, s 43.

${ }^{7}$ Children Act 2004, c 31, s 58.

${ }^{8}$ Criminal Code, above n 6.

${ }^{9} \mathrm{~s} 43$ reads as follows:
}

Every schoolteacher, parent or person standing in the place of a parent is justified in using force by way of correction toward a pupil or child, as the case may be, who is under his care, if the force does not exceed what is reasonable under the circumstances.

${ }^{10}$ As discussed below, judicial interpretation of the Canadian statutory defence in Canadian Foundation brings it into line with the UK's legislative position.

${ }^{11}$ Education Act 1996, c 56, s 548, as substituted by School Standards and Framework Act 1998, c 31, s 131(1).

12 Day Care and Child Minding (National Standards) (England) Regs 2003, para 5 (SI 2003/1996).

${ }^{13}$ Canadian Foundation for Children, Youth and the Law v Canada (Attorney General) 2004 SCC 4.

${ }^{14}$ A constitutional challenge without facts might be a missed opportunity - both to demonstrate respect for children through participation and to make more likely child-centred reasoning and a better outcome for children. Children value participation: Chelsea Marshall, Bronagh Byrne and Laura Lundy, 'Face to Face: Children and Young People's Right to Participate in Public Decision-making' in Tali Gal and Benedetta Faedi Duramy (eds), International Perspectives and Empirical Findings on Child Participation: From Social Exclusion to Child-Inclusive Policies (Oxford, Oxford University Press, 2015) 357-80. Participation can enable children to develop as rightsholders: Emily Buss, 'What the Law Should (and Should Not) Learn from Child Development Research' (2009) 38 Hofstra Law Review 13-68. But the missed opportunity was not necessarily for a 'children's rights' approach. In $R$ (Williamson) $v$ Secretary of State for Education and Employment and Others [2005] UKHL 15, Baroness Hale highlighted the need for children's participation and inclusion, but did so within an approach that saw children as holding 'rights' rather than 'children's rights': [71]. 
driven by Ailsa Watkinson, who secured funding from the Court Challenges Program and approached the Foundation to take the case forward to court. ${ }^{15}$ There was widespread media coverage as the case progressed through the various levels of hearing and appeal ${ }^{16}$ and, as demonstrated by the large number of organisations that sought to act as interveners, ${ }^{17}$ significant issues of public policy were at stake.

\section{A. Issues before the Supreme Court of Canada}

The appellant, the Foundation, sought a declaration that section 43 infringed three sections of the Canadian Charter of Rights and Freedoms. ${ }^{18}$ In particular, the Foundation argued that section 43 infringed: section 7, the right to life, liberty and security of the person, of which a person cannot be deprived except in accordance with principles of 'fundamental justice', because it failed to give procedural protections to children, did not further the 'best interests' of the child, and was both overbroad and vague; section 12 , the right not to be subjected to cruel and unusual treatment or punishment, because physical punishment fell within the terms of section 12; and section 15(1), the right to equality before the law, because it denied children the legal protection against assaults that was accorded to adults. The Foundation further argued that, if section 43 infringed any of those sections, such infringement could not be saved by section 1 of the Charter as a 'reasonable limit[] prescribed by law as can be demonstrably justified in a free and democratic society'.

\footnotetext{
${ }^{15}$ Ailsa M Watkinson, 'Human Rights Legislation, Court Rulings, and Social Policy' in Anne Westhues (ed), Canadian Social Policy: Issues and Perspectives 4th rev ed (Waterloo ON, Wilfred Laurier Press, 2006) 69-89, 79.

${ }^{16}$ See, for example, Corinne Robertshaw, 'Spare the law and kill the child' Globe and Mail (18 April 2002), online: www.theglobeandmail.com/globe-debate/spare-the-law-and-kill-the-child/article754215/.

${ }^{17}$ Watkinson, above n 15, 79.

${ }^{18}$ Part 1 of the Constitution Act, 1982, being Schedule B to the Canada Act 1982 (UK) 1982, c. 11.
} 
Both the Ontario Supreme Court ${ }^{19}$ and Court of Appeal ${ }^{20}$ rejected the Foundation's contentions and held that section 43 was constitutional.

\section{B. The Supreme Court's Reasoning}

The Supreme Court of Canada held, by a majority, that section 43 did not unjustifiably infringe sections 7,12 , or 15(1) of the Charter and dismissed the Foundation's appeal.

There are four substantive judgments - a majority (McLachlin CJ, with whom Gonthier, laccobucci, Major, Bastarache and LeBel JJ agreed), a partial dissent (Binnie J), and two dissents for different reasons (Arbour J; Deschamps J).

A majority of seven (McLachlin CJ's majority judgment and Binnie J) held that section 43 did not infringe the section 7 right to life, liberty and security of the person. ${ }^{21}$ The majority demarcated a clear, protected space for physical punishment of children by first 'reading down' section 43 and establishing 15 qualifications on the substantive defence, intended to clarify the requirement that the punishment be 'reasonable under the circumstances ${ }^{\prime 22}$ and that, in direct contradiction of the wording of section 43 , teachers were outwith the scope of the defence. ${ }^{23}$ Only then, after creating a prospective interpretation that ignored the significant evidence of prior inconsistency in practice, ${ }^{24}$ did McLachlin CJ ask whether section 43 was unconstitutional for vagueness. ${ }^{25}$ As Arbour J commented, 'it is useful to note how much work must go into making the provision constitutionally sound and sufficiently precise'. ${ }^{26}$ Whilst 'unusual', the majority's

\footnotetext{
${ }^{19}$ Canadian Foundation for Children, Youth and the Law v Canada (Attorney General) [2000] OJ No 2535 (Ont SCJ).

${ }^{20}$ Canadian Foundation for Children, Youth and the Law v Canada (Attorney General) [2002] OJ No 61 (Ont CA). Goudge JA gave the judgment of the court.

${ }^{21}$ Canadian Foundation, above n 13, [70.1] (McLachlin CJ), [130.1] (Binnie J).

22 ibid [39]-[40] (McLachlin CJ).

23 ibid [40] (McLachlin CJ).

${ }^{24}$ Arbour J convincingly demonstrates the inconsistent meaning given to 'reasonable' in the prior body of case law: ibid [181]-[182] (Arbour J).

25 ibid [42] (McLachlin CJ).

26 ibid [190] (Arbour J).
} 
'aggressive' 'reading down' has been characterised as an 'increasingly familiar strategy... to cure elements of residual unconstitutionality'. ${ }^{27}$ Arbour J dissented, and relied solely on this ground to conclude that section 43 of the Criminal Code was unconstitutional. ${ }^{28}$ Whilst Deschamps J agreed with Arbour J's reasoning on this point, she preferred to resolve the constitutionality of section 43 under section $15(1) .^{29}$

The same majority of seven held that section 43 did not infringe the section 12 right to be free from cruel and unusual treatment or punishment. ${ }^{30}$ Neither Arbour J nor Deschamps J considered it necessary to decide this point. ${ }^{31}$

A majority of six (McLachlin CJ's majority judgment) held that section 43 did not infringe the section 15(1) right to equality before the law. ${ }^{32}$ Arbour J did not consider it necessary to decide this point. ${ }^{33}$ Deschamps J, dissenting, relied solely on this ground to conclude that section 43 was unconstitutional. ${ }^{34}$ Binnie J purported to agree with Deschamps J on this issue, albeit it for somewhat different reasons. ${ }^{35}$ He dissented in part, in relation to teachers, but not parents or persons standing in the place of parents. ${ }^{36}$ In respect of the latter, he reasoned that the prima facie infringement of section 15(1) was justified under section $1 .^{37}$

Arbour and Deschamps JJ proposed striking down as the appropriate remedy. ${ }^{38}$ In his partial dissent in respect of teachers, Binnie J proposed only a declaration of unconstitutionality. ${ }^{39}$ Advocating the repeal of section 43 does not necessarily entail

\footnotetext{
${ }^{27}$ Jamie Cameron, 'From the MVR to Chaoulli v Quebec: The Road Not Taken and the Future of Section 7' (2006) 34 Supreme Court Review 105-65, 128.

${ }^{28}$ Canadian Foundation, above n 13 [211.2] (Arbour J).

29 ibid [213], [246.1-2] (Deschamps J).

30 ibid [70.3] (McLachlin CJ), [130.3] (Binnie J).

31 ibid [211.3] (Arbour J), [246.3] (Deschamps J).

32 ibid [70.5] (McLachlin CJ).

33 ibid [211.5] (Arbour J).

34 ibid [246.5-6] (Deschamps J).

35 ibid [73] (Binnie J).

36 ibid [129], [130.6] (Binnie J).

37 ibid [130.6] (Binnie J).

38 ibid [194] (Arbour J), [242] (Deschamps J).

39 ibid [129] (Binnie J).
} 
supporting a complete ban on all forms of physical punishment. ${ }^{40}$ There are relevant defences in the general law, namely de minimis and necessity. Even in the absence of such defences, a complete ban does not necessarily mean that there can be no overlooked physical punishment. The interpretation of the section 265 offence of assault leaves space for declaring the definitional threshold not met in particular cases; thus, a child may be physically punished without triggering a legal response.

On the basis of the general law defences, Arbour J reasoned that she had 'come to a conclusion which may not be very different from that reached by the Chief Justice'. ${ }^{41}$ Given her dissent on the basis of section 7, she was suggesting that courts would likely reach similar outcomes in future cases whether 'reading down' section 43 or prima facie criminalising all instances of physical punishment subject to the applicability of the de minimis and necessity defences. But this outcome-oriented construction of 'rights' may pay insufficient attention to rights' expressive function. ${ }^{42}$

Academic criticism of the Court's decision has been wide-ranging, extending from targeting the Court's remedial reinterpretation of section 43 to preserve its constitutionality ${ }^{43}$ to focusing on its failure to clarify whether there is in fact a de minimis defence in criminal law. ${ }^{44}$

\footnotetext{
${ }^{40}$ Sweden, for example, adopted a two-stage approach to parents: first, it removed the defence in 1966; then, in 1979 it introduced an explicit ban. See Staffan Janson, Bodil Långberg, and Birgitta Svensson, 'Sweden: A 30Year Ban on Physical Punishment of Children' in Joan E Durrant and Anne B Smith (eds), Global Pathways to Abolishing Physical Punishment: Realizing Children's Rights (Abingdon, Routledge, 2011) 241-55, 245-47.

${ }^{41}$ Canadian Foundation, above n 13, [131] (Arbour J).

42 Though note that elsewhere I argue the expressive and procedural aspects of rights are contingent on outcomes, including potential for better outcomes for children. See Lucinda Ferguson, 'Not Merely Rights for Children but Children's Rights: The Theory Gap and the Assumption of the Importance of Children's Rights' (2013) 21 International Journal of Children's Rights 177-208.

${ }^{43}$ See, for example, Cameron, above n 27, 128.

${ }^{44}$ See, for example, Sanjeev Anand, 'Reasonable Chastisement: A Critique of the Supreme Court's Decision in the "Spanking Case"" (2004) 41 Alberta Law Review 871-78 (not paginated). See also Megan Elizabeth Rosborough, The 'Spanking Defence': Canadian Foundation for Children, Youth and the Law v Canada and the Future of Reasonable Correction of Children by Force in Canada, LLM Thesis (University of Alberta, 2011) 108, 117-21.
} 


\section{Grover J's Reimagined Dissent}

In order to hold section 43 constitutional, the majority of the Court must demonstrate that it does not unjustifiably infringe any of the three proposed sections of the Charter. To conclude that section 43 is unconstitutional, the dissent need only show that one of the three sections has been unjustifiably infringed.

In focusing on section 15(1), Deschamps J centred on the issue of equality between children and adults, and thereby put the larger, political debate at the centre of the case. The difficulty with taking such a stance is that the physical punishment of children was a 'controversial social issue' ${ }^{45}$ and 'divisive'. ${ }^{46}$ Canadian public sentiment at the time of Canadian Foundation is characterised by complexity, and divergence between individuals' attitudes and behaviours. In 2004, Durrant et al reported research from 1988 that found that more than 75 per cent of parents surveyed believed 'that physical punishment is harmful to children and unnecessary'. ${ }^{47}$ Yet, they also noted 2003 research findings that 70 per cent of surveyed mothers of preschool children in Manitoba reported that they had used physical punishment, one in three of whom stated that they used it at least weekly. ${ }^{48}$ Similarly, Rosborough cites a public opinion survey from 2002, which found that 70 per cent of Canadian parents were opposed to a legal ban on physical punishment. ${ }^{49}$ This demonstrates the difficulties for Grover J to ground her reimagined dissent in section 15(1).

In instead relying on section 7, Arbour J arguably sought to avoid taking a stance on that issue. Perhaps because of the technical nature of the section 7 route to unconstitutionality, Grover J instead holds section 43 unconstitutional for unjustifiably infringing section 12 . Whilst she does not frame her analysis as addressing section 7 , she agrees with Arbour J's reasoning against first 'reading down' section 43 before assessing its

\footnotetext{
${ }^{45}$ Canadian Foundation, above n 13, [185] (Arbour J).

${ }^{46}$ Anand, above $\mathrm{n} 44$.

${ }^{47}$ Durrant et al, above n 1, 3 .

48 Joan E Durrant, Linda Rose-Krasnor and Anders G Broberg, 'Maternal Beliefs about Physical Punishment in Sweden and Canada' (2003) 34 Journal of Comparative Family Studies 586-604, 593.

${ }^{49}$ Rosborough, above n 44, fn 391 and corresponding main text.
} 
constitutionality. ${ }^{50}$ She also endorses an enlarged role for the de minimis and necessity defences. ${ }^{51}$ Dissenting on section 7 grounds also invites taking a view on children's 'best interests' as a principle of 'fundamental justice'; ${ }^{52}$ this treats children as distinct from adults. Within the terms of her section 12 argument, Grover J instead focuses on human dignity, a concept applicable to children and adults alike. ${ }^{53}$ The section 12 route enables Grover J to approach the issue of physical punishment on the assumption of the equal status of children and adults, albeit in terms of human rights (or 'rights for children'), rather than children's rights. $^{54}$

\section{Critique of Grover J's Reimagined Dissent}

There are two perspectives from which Grover J's judgment should be evaluated: first, the extent to which the detail of the section 12 argument is successful; and, second, the value of assuming the equal status of children and adults.

\section{A. The Detail of the Section 12 Reimagined Dissent}

It is undisputed that teachers are state actors. The success of Grover J's section 12 argument requires her to satisfy three points: first, that parents are also state actors; ${ }^{55}$ second and relatedly, that the state's role here comprises positive action; and third, that section 12 is applicable outside of the criminal context. This is an ambitious argument,

\footnotetext{
${ }^{50}$ Rewritten judgment [26].

${ }^{51}$ Rewritten judgment [20].

${ }^{52}$ Canadian Foundation, above n 13, [7] (McLachlin CJ); see also [10].

${ }^{53}$ Rewritten judgment [18].

${ }^{54}$ Lucinda Ferguson, 'The Jurisprudence of Making Decisions Affecting Children: An Argument to Prefer Duty to Children's Rights and Welfare' in Alison Diduck, Noam Peleg and Helen Reece (eds), Law in Society: Reflections on Children, Family, Culture and Philosophy - Essays in Honour of Michael Freeman (Leiden, Brill, 2015) 141-89, 143-44. See also Ferguson, above n 38, especially 179-92.

${ }^{55}$ Rewritten judgment [5]-[13].
} 
aimed at dispelling the common assumption that there is anything truly private in the familial context so as to secure full protection for children regardless of the setting.

The usual view is that the state simply provides a defence for the use of physical punishment by others. If parents are state actors, however, parents' positive actions thereby become the active state imposition ${ }^{56}$ of physical punishment. This is an unconventional perspective and likely to be controversial. For example, shortly after its judgment in Canadian Foundation, the UK House of Lords in R (Williamson) $v$ Secretary of State for Education and Employment and Others ${ }^{57}$ demarcated schoolteachers as outwith the defence available to parents, and rejected the argument that there could be any circumstances in which teachers could exercise a parent's right to use physical punishment, even if the parents explicitly sought to delegate it. ${ }^{58}$

Grover J contrasts the exercise of a parental liberty right with the delegated exercise of state power, and argues that both teachers and parents physically punish children via the latter. ${ }^{59}$ Hill has previously set out a broader account on identical lines. ${ }^{60}$ There are two critical difficulties with this argument. First, in vital respects, Grover J elides the more straightforward position of teachers with the 'more complex' ${ }^{61}$ family setting involving parents. $^{62}$ Grover J acknowledges the State has afforded parents... a certain constitutional scope of private activity', ${ }^{63}$ yet does not consider the implications of this point for her assertion that 'the parent, parental delegate or teacher acts as an agent of the State'. ${ }^{64}$ In agreeing with Binnie J that teachers using physical punishment are not exercising a parental

\footnotetext{
56 See Dwight Newman, 'Cruel and Unusual Punishment' in Halsbury's Laws of Canada - Constitutional Law (Charter of Rights) (LexisNexis Canada, 2014 reissue) HCHR-94.

${ }^{57}$ Above $\mathrm{n} 14$.

58 ibid [12]-[13] (L’Nicholls).

${ }^{59}$ Rewritten judgment [7].

${ }^{60}$ B Jessie Hill, 'Constituting Children's Bodily Integrity' (2015) 64 Duke Law Journal 1295-362, 1305 (positing parents as exercising state power via delegation).

${ }^{61}$ Williamson, above n 14, [84] (B'Hale).

${ }^{62}$ For example, rewritten judgment [5]-[7], though note the additional, separate discussion of parents ([12][14]) and teachers ([15]).

${ }^{63}$ Rewritten judgment [12].

${ }^{64}$ Rewritten judgment [5]. In respect of parents in particular: 'I hold that parents as section 43 'persons-inauthority' act as delegates of the State in exercising authority under shield of section 43': [12].
} 
liberty interest and acting in loco parentis, ${ }^{65}$ this invites Binnie J's solution, whereby parents' use of physical punishment can be so grounded. Whereas the phrasing of section 43 treats a 'schoolteacher' as a distinct category from both a 'parent' and a 'person standing in the place of a parent', Grover J posits that 'the separate listing... is not to distinguish a separate status/grounding. ${ }^{66}$ Yet, the distinctiveness of parents' position is reinforced by the Supreme of Canada's reasoning in Ogg-Moss $v$ R. ${ }^{67}$

Second, there is no Canadian or persuasive comparative authority that treats the parental use of physical punishment as positive state action. Whilst Grover J cites Supreme Court of Canada decisions, none substantiate this point without requiring further assumptions. For example, in his majority concurring judgment in $B(R) v$ Children's Aid Society of Metropolitan Toronto, ${ }^{68}$ La Forest J reasoned that '[the parental] liberty interest is not a parental right tantamount to a right of property in children' ${ }^{69}$ But this only supports the case against the section 43 defence on the assumption that the use of physical punishment does, as Grover J asserts, 'render children akin to property', ${ }^{70}$ the case for which remains to be made.

In terms of comparative sources, Grover J cites Campbell and Cosans v United Kingdom ${ }^{71}$ regarding the limits of teachers' and parents' 'parental liberty right' ${ }^{72}$ Campbell cannot ground that contention since the European Court of Human Rights (ECtHR) itself states both that it sees teachers' and parents' 'power of chastisement' as separately grounded and that neither is in the form of delegated state power. ${ }^{73}$ Further, Grover J suggests that the ECtHR in A v United Kingdom (Human Rights: Punishment of Child) ${ }^{74}$ held

\footnotetext{
${ }^{65}$ Rewritten judgment [9].

${ }^{66}$ Rewritten judgment [9] (emphasis in original).

${ }^{67}$ Ogg-Moss $v R$ [1984] 2 SCR 173, especially 190-92 (Dickson J).

${ }^{68} B(R) v$ Children's Aid Society of Metropolitan Toronto [1995] 1 SCR 315.

${ }^{69} B(R)[85]$ (La Forest J).

${ }^{70}$ Rewritten judgment [12].

${ }^{71}$ Campbell and Cosans v United Kingdom Application no 7511/76; 7743/76) (23 February 1982) (ECtHR).

72 Rewritten judgment [12], citing Campbell and Cosans, ibid [36].

${ }^{73}$ Campbell and Cosans, ibid [12].

${ }^{74}$ A v United Kingdom (Human Rights: Punishment of Child) [1998] 2 FHR 959 (ECtHR).
} 
that the stepfather's actions violated the child's Article 3 ECHR right. ${ }^{75}$ In fact, the unjustifiable violation was the state's failure to adequately prevent or respond to the stepfather's actions. ${ }^{76}$

Grover J draws on the US case law discussed by Hill. ${ }^{77}$ In particular, she cites the US Supreme Court's decision in Ingraham $v$ Wright ${ }^{78}$ to evidence that teachers exercise delegated state power ${ }^{79}$ but, for the purpose of her argument in respect of parents, overlooks that the court in Ingraham distinguished between parents and teachers. ${ }^{80} \mathrm{Hill}$ recognises that the argument that parents exercise delegated state power is both doctrinally and conceptually difficult, ${ }^{81}$ though finds it ultimately compelling. ${ }^{82}$

But the view that parental decision-making is simply the delegated exercise of state power contains no natural limits. It treats all individuals' actions not prohibited by the state and/or protected by a state defence as state action, and suggests that there is no scope for any private domain of family life. Families are afforded a measure of protection from state interference because they are 'irreplaceable' in modern liberal society; ${ }^{83}$ 'different families are tolerated only so long as their adult members discharge the morally fundamental duty to provide adequate care for children' ${ }^{84}$ This is evidenced by the existence of a threshold for child protective intervention. Hill is correct that Foucault 'demonstrates the pervasiveness of state power and its implications', ${ }^{85}$ but recognising that state power permeates familial relationships does not make parents state actors for legal purposes.

\footnotetext{
${ }^{75}$ Rewritten judgment [10].

${ }^{76} A v U K$, above $\mathrm{n} 74$, [24].

${ }^{77}$ Hill, above n 60.

78 Ingraham v Wright 430 US 651 (1977) (US Supreme Court).

${ }^{79}$ Rewritten judgment [16].

${ }^{80}$ Ingraham, above n 78, 662, as cited ibid.

${ }^{81}$ Hill, above n 60, $1336 \mathrm{ff}$.

${ }^{82}$ Hill contends that it does not make sense that the US courts have constitutionalised children's right to bodily integrity in the abortion context: above $\mathrm{n} 60,1314$. Yet, as Hill notes, that right is underpinned by both autonomy and protection against bodily harm understood in terms of best interests: ibid 1317-18. In other contexts such as physical punishment, however, it is not clear that those twin concerns of autonomy and best interests similarly combine to exclude any space for parental decision-making.

${ }^{83}$ David Archard, The Family: A Liberal Defence (London, Palgrave Macmillan, 2010) 117.

84 ibid 118.

${ }^{85}$ Hill, above n 60, 1347.
} 
Recognising that the state permits parents a 'privileged sphere' ${ }^{86}$ of familial interactions, and a measure of protection from state interference does not mean that parental action within that protected domain is state action for legal purposes qua exercise of delegated state power. In this way, the doctrinal concern over identifying state action in the family context collapses into the conceptual concern over the state's scrutiny of the limits of any private domain.

Through the existence of a legal regime, the state regulates all individual actions and inactions, whether through positive intervention or lack of intervention. Individuals' actions qualify as the exercise of delegated state power only if these individuals are acting qua the state. Individuals acting within the private family sphere, which is protected by the state from state interference, are not. The state action is in the provision of the defence, not the underlying physical action protected by the defence. ${ }^{87}$ Otherwise, a victim of domestic violence who is able to rely on the defence of diminished responsibility is thereby an agent of the state, rather than a victim. The conceptual argument cannot be sustained.

The third matter on which Grover J's argument turns is that, contrary to the general understanding, section 12 is applicable outside of the criminal context. ${ }^{88}$ Drawing on the open-textured language of the section itself, Grover J asserts that section 12 is not restricted to penal sentencing and the judicial context. ${ }^{89}$ Outside of sentencing, however, section 12 case law remains confined to issues of criminal process; prison treatment; and immigration. ${ }^{90}$ In arguing for broader application, Grover J cites Kindler, ${ }^{91}$ a case concerned with extradition for criminal proceedings, and Rodriguez, ${ }^{92}$ a case in which the Supreme Court assumed that section 12 could apply more broadly only so as to enable it to determine whether the section could have been infringed in any event. In addition, the

\footnotetext{
${ }^{86}$ John Eekelaar, Family Law and Personal Life (Oxford, Oxford University Press, 2006) 82.

${ }^{87}$ In her reimagined dissent, Grover J confounds the distinction ([10]), discussed above at n $75-\mathrm{n} 76$ and corresponding main text.

${ }^{88}$ See also Ingraham, above n 78 and corresponding main text.

${ }^{89}$ Rewritten judgment [22].

90 Newman, above n 56.

${ }^{91}$ Kindler v Canada (Minister of Justice) [1991] 2 SCR 779, cited rewritten judgment [23].

92 Rodriguez v British Columbia (Attorney General) [1993] 3 SCR 519, cited rewritten judgment [22].
} 
majority in the US case of Ingraham, ${ }^{93}$ a case on which Grover J relies elsewhere, held that the ban on 'cruel and unusual punishment' did not apply to the non-criminal context. ${ }^{94}$

In addition to these three context-specific hurdles to sustaining her section 12 argument, Grover J must also demonstrate that either any physical punishment or at least that which exceeds de minimis falls within the terms of 'cruel' or 'unusual' treatment or punishment. From her reference to 'especially that beyond de minimis', it is unclear whether Grover J regards the failure to criminalise all physical punishment as unconstitutional or only that which meets a de minimis threshold. ${ }^{95}$ Grover J relies on their conclusion to contend that that majority's definition is 'circular'.$^{96}$ In their judgment, however, the majority first determined that the conduct covered by section 43 was 'reasonable' within the terms of section 7 , and then were logically bound to conclude that section 12 could not be violated:

Conduct cannot be at once both reasonable and an outrage to standards of decency. Corrective force that might rise to the level of 'cruel and unusual' remains subject to criminal prosecution. ${ }^{97}$

Whilst ambitious, there are thus significant difficulties to sustaining the detail of Grover J's section 12 argument. Yet, as discussed above, there is clear strategic value in the attempt to make the section 12 case rather than rely on either section 15(1) or section 7.

\section{B. The Assumption of Equal Status}

None of the Court's judgments referred to children's rights. The ongoing availability of particular defences to the physical punishment of children stands in stark contrast to the increasing use of children's rights to frame legal regulation, as well as the evaluation

\footnotetext{
${ }^{93}$ Ingraham, above $\mathrm{n} 78$.

94 ibid 664.

95 Rewritten judgment [17], [18].

${ }^{96}$ Rewritten judgment [23].

${ }^{97}$ Canadian Foundation, above n 13, [49] (McLachlin CJ).
} 
thereof. ${ }^{98}$ This makes the physical punishment of children a critical site for determining what it means for children to be rightsholders, whether of (human) rights for children or children's rights.

Insofar as children should be seen as holding human rights just as adults because they 'are entitled to the same moral consideration as adults', ${ }^{99}$ this is a powerful point in favour of Grover J's approach. She justifies reasoning in terms of human rights on the basis that 'there are currently few if any instances of recognised arguably non-derogable specific "children's rights"'. ${ }^{100}$ Whilst that is not itself an obstacle to adopting a children's rights approach, one might wonder if reclaiming the equalising status of human rights is more desirable. This is especially so, given that children are rightsholders under the Charter, ${ }^{101}$ which suggests it should be necessary to either assume the equal applicability, or at least justify the unequal applicability of rights to children and adults. Otherwise, the majority's decision may be seen as realising the risk that a human rights model can 'descend into the co-option or appropriation of a rights based approach by existing power structures' ${ }^{102}$

One might wonder if the similar consequences of the decision of the European Court of Human Rights in $A v U K^{103}$ are at least in part attributable to the human rights basis of the reasoning. Whilst the ECtHR held that the UK government owed the child a positive obligation to provide practical and effective state protection against treatment or punishment contrary to Article $3 \mathrm{ECHR}^{104}$ the decision related only to that specific case ${ }^{105}$ and the ECtHR stressed that only physical punishment of 'sufficient severity' ${ }^{106}$ would

\footnotetext{
${ }^{98}$ For example, consider the increasing use and importance of variously-titled children's or child rights impact assessments in respect of proposed legislation and budgetary reform.

${ }^{99}$ Samantha Brennan and Robert Noggle, 'The Moral Status of Children: Children's Rights, Parents' Rights, and Family Justice’ (1997) 23 Social Theory and Practice 1-26, 2.

${ }^{100}$ Rewritten judgment [29].

${ }^{101}$ As under the European Convention on Human Rights, children are not explicitly mentioned in the Charter. Charter rights are treated as extending to children yet, in practice, they are of limited application.

102 John Tobin, 'Understanding a Human Rights Based Approach to Matters Involving Children: Conceptual Foundations and Strategic Considerations' in Antonella Invernizzi and Jane Williams (eds), The Human Rights of Children: From Visions to Implementation (Abingdon, Routledge, 2011) 61-98, 90.

${ }^{103} A v U K$, above $\mathrm{n} 74$.

${ }^{104}$ Convention on Human Rights and Fundamental Freedoms, Rome 4 XI 1950 [ECHR].

${ }^{105} A v U K$, above $\mathrm{n} 74,[19]$.

106 ibid [23].
} 
infringe Article 3. Insofar as the ECtHR held Article 3 violated and the majority of the Supreme Court did not hold the Charter infringed, the outcomes reached differ. Yet, the consequences for future cases are nearly identical; the limits introduced by section 58 of the Children Act 2004 can be neatly contrasted to McLachlin CJ's15 qualifications. ${ }^{107}$ Might a distinctive children's rights model have been more robustly applied?

Would reframing the legal issue in terms of children's rights be more likely to invert the premise of the section 43 debate than a human rights perspective? The current approach to physical punishment unjustifiably assumes children should be treated differently to adults, and then considers arguments for equal treatment. Given that, as Grover J argues, children hold the same human rights as adults in this context, why do we not assume equal treatment and then consider whether we have sufficient justification for othering children? Approaching the issue in terms of children's and adults' equal (human) rights for children ought to highlight the unjustified disparate starting-points. Yet, the different language of children's rights is sometimes the critical impetus for truly equal treatment. Further, the Committee on the Rights of the Child has suggested that

[t]he distinct nature of children, their initial dependent and developmental state, their unique human potential as well as their vulnerability, all demand the need for more, rather than less, legal and other protection from all forms of violence. ${ }^{108}$

To the extent that a children's rights approach prioritises children's interests, ${ }^{109}$ the Committee's analysis supports the different language of children's rights in order to achieve different, better protection for children.

Finally, in relation to the human dignity basis for Grover J's argument, it is noteworthy that, post-Canadian Foundation, it has been rejected as an aspect of the legal

\footnotetext{
107 Canadian Foundation, above n 13, [40] (McLachlin CJ).

${ }^{108}$ United Nations' Committee on the Rights of the Child, General Comment No 8 (2006): The right of the child to protection from corporal punishment and other cruel or degrading forms of punishment (arts 19; 28, para 2; and 37, inter alia), CRC/C/GC/8 [21].

${ }^{109}$ For a detailed argument to this effect, see Lucinda Ferguson, 'The Case for Treating Children as a "Special Case"" in Elizabeth Brake and Lucinda Ferguson (eds), Philosophical Foundations of Children's and Family Law (Oxford, Oxford University Press, 2017) (forthcoming).
} 
test for section 15(1) due to the excessive burden it placed on claimants. ${ }^{110}$ Might this also cast doubt on its value for Grover J's section 12 argument?

\section{Government Commitment to Change}

Grover J's reimagined dissent supports the existing dissenting judgments in Canadian Foundation and completes the trio of Charter arguments whereby the Supreme Court could have concluded that section 43 was unconstitutional. This is vital because of the harms of physical punishment. In 2012, drawing on 20 years of research, Durrant and Ensom concluded that 'no study has found that physical punishment enhances developmental health' ${ }^{111}$ Watkinson comments that, whilst 'the result was not what [she] had hoped for, it still reaped some benefits ${ }^{112}$ and highlights the extent to which the decision increased public awareness of the empirical evidence. ${ }^{113}$ To the extent that social attitudes have changed, however, it is not clear that they changed as a result of Canadian Foundation. In 2012, Bell and Romano found that, of the 818 non-parents they surveyed, 'individuals were more or less evenly divided as to whether the law giving parents the right to use reasonable force in disciplining their children should be upheld or removed'.114 In particular, 38.6 per cent held favourable views towards section 43 and 25.8 per cent were favourable towards 'spanking' generally. ${ }^{115}$

\footnotetext{
${ }^{110} R v$ Kapp 2008 SCC 41 [20]-[21] (McLachlin CJ, Abella J).

${ }^{111}$ Joan Durrant and Ron Ensom, 'Physical Punishment of Children: Lessons from 20 Years of Research' (2012) 184(12) Canadian Medical Association Journal 1373-77, 1373. A minority of scholars do persist in arguing to the contrary. See, for example, Jason M Fuller, 'The Science and Statistics Behind Spanking Suggest that Laws Allowing Corporal Punishment Are in the Best Interests of the Child' [2015] 42 Akron Law Review Issue 1, Article 7.

${ }^{112}$ Watkinson, above n $15,78$.

113 ibid 81 (citing Durrant et al, above n 1).

114 Tessa Bell and Elisa Romano, 'Opinions About Child Corporal Punishment and Influencing Factors' (2012) 27(11) Journal of Interpersonal Violence 2208-29, 2221.

115 ibid 2217-18.
} 
In his judgment in the Ontario Superior Court of Justice, McCombs J reviewed approaches taken in other jurisdictions, including the UK government's response to the European Court of Human Rights in $A v \cup K$, and concluded that they revealed 'a consensus that the most appropriate way of addressing this issue is to develop educational and other social programs designed to change social attitudes, rather than to expand the reach of criminal law' ${ }^{116}$ But the Canadian government did not initiate any such public education campaign in response to the Court's decision in Canadian Foundation. ${ }^{117}$

If the harm is clear, and progress with social attitudes is slow, can we justify waiting for social change? That difficult question looks to have been avoided. In December 2015, Prime Minister Trudeau affirmed the Liberal government's commitment to implement every one of the 94 recommendations made by the Truth and Reconciliation Commission on Indian residential schools. ${ }^{118}$ This has critical, broader ramifications as recommendation 6 is to repeal section $43 .{ }^{119}$ Canada thus stands on the verge of equal treatment and respect for children and adults in the law on assault. The language of 'reasonable correction' will lose its power; in turn, children will gain theirs.

\footnotetext{
${ }^{116}$ Canadian Foundation (Ont SCJ), above n 17, [104] (McCombs J). This also accords with emerging evidence from Sweden regarding the difficulty of educating parents in the context of a pre-existing ban, which can cause professionals to worry about stigmatising parents and parents to be concerned about the ramifications of 'confessing' that they need support: Pernilla Leviner, 'The Swedish Prohibition against Corporal Punishment from a Comparative Perspective - Effects and Challenges' (2015) 61 Scandinavian Studies in Law 219-46, 243.

${ }^{117}$ Anne McGillivray and Cheryl Milne, 'Canada: The Rocky Road of Repeal' in Durrant and Smith, above $\mathrm{n}$ 40, 98-111, 105.

118 Joanne Smith, 'Liberal government commits to repealing "spanking law", OurWindsor.ca (21 December 2015) online: www.ourwindsor.ca/news-story/6203504-liberal-government-commits-to-repealing-spankinglaw-l.

119 Truth and Reconciliation Commission, Canada's Residential Schools: Reconciliation - The Final Report of the Truth and Reconciliation Commission of Canada, Volume 6 (Truth and Reconciliation Commission of Canada 2015) 224, online: www.myrobust.com/websites/trcinstitution/File/Reports/Volume_6_Reconciliation_English_Web.pdf.
} 